\title{
Immune complex vasculitis: a rash that cannot be missed
}

\author{
Michelle Koch, ${ }^{1}$ Zalan Khan, ${ }^{2}$ Ethan M Karle, ${ }^{3}$ Tarang P Patel ${ }^{3}$
}

${ }^{1}$ School of Medicine, University of Missouri System, Columbia, Missouri, USA

${ }^{2}$ Department of Neurology, University of Missouri System, Columbia, Missouri, USA ${ }^{3}$ Department of Medicine, University of Missouri System, Columbia, Missouri, USA

\section{Correspondence to} Dr Tarang P Patel; tppd45@gmail.com

Accepted 26 January 2020

\section{DESCRIPTION}

A 43-year-old woman with a medical history of chronic obstructive pulmonary disease, type II diabetes mellitus, hypertension, irritable bowel syndrome, osteoarthritis, epilepsy and methamphetamine use presented to the emergency department with a diffuse erythematous maculopapular rash with palpable purpura (figure 1A). Patient endorsed the rash had been present 3 days prior to presenting to the emergency department. The rash initially only involved her ankles before migrating to her thighs, buttocks, abdomen, wrists and hands. She described it as pruritic, burning and painful. The patient also described significant myalgias and arthralgias. Vital signs on arrival: temperature of $37.1^{\circ} \mathrm{C}$, heart rate of 102 beats/min, respiratory rate of 20 breaths $/ \mathrm{min}$, blood pressure of $146 / 75 \mathrm{~mm}$ $\mathrm{Hg}$ and $\mathrm{SpO}_{2}: 98 \%$ on room air. Laboratories were significant for a white cell count of $11.7 \times 10^{9} / \mathrm{L}$, haemoglobin of $112 \mathrm{~g} / \mathrm{L}$, erythrocyte sedimentation rate of $38 \mathrm{~mm} /$ hour and a C-reactive protein level of $5.8 \mathrm{mg} / \mathrm{dL}$. Given the patients presenting symptoms and associated rash, there was concern for immune complex vasculitis; with confirmation of leucocytoclastic vasculitis (LCV) on skin biopsy. Investigation into the aetiology of the patient's LCV was negative for HIV, causative medications, antiphospholipid syndrome and systemic lupus erythematosus (SLE). Further infectious workup only revealed positive hepatitis $\mathrm{C}$ antibodies but with a negative viral load. Oral glucocorticoids were initiated, and pain control was achieved with opiates and non-steroidal anti-inflammatories. The patient's systemic symptoms along with her rash

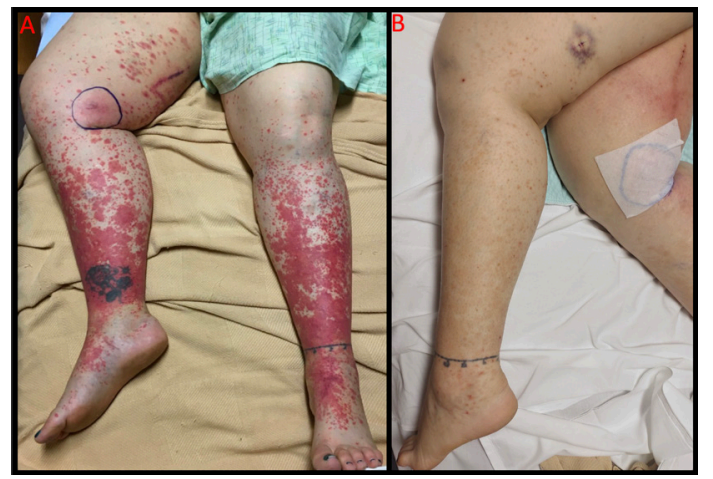

Figure 1 (A) Lower extremities with red to purple macules and papules, some of which are coalescing into larger patches and plaques. (B) Lower extremities demonstrating marked improvement of rash after initiation of corticosteroids.

\section{Learning points}

- The rash of immune complex vasculitis most commonly presents with painful, palpable purpura starting in the lower extremities.

- Common causes of leucocytoclastic vasculitis (LCV) are infections (hepatitis C virus and HIV), autoimmune disorders (Sjogren syndrome and systemic lupus erythematosus), medications, malignancy and vascular disorders.

- When LCV is limited to the skin, management is supportive while corticosteroids and immunosuppressive agents are typically reserved for systemic involvement.

demonstrated rapid improvement 24 hours after initiation of glucocorticoids (figure 1B).

Immune complex vasculitis is a small-vessel vasculitis that typically presents with palpable, burning purpura most often found in the lower extremities. Further study of palpable purpura can be accomplished by using diascopy (pressing a glass slide against a cutaneous lesion). ${ }^{1}$ Immune complex vasculitis can present with systemic involvement; affecting joints, muscles, the gastrointestinal tract and renal system. Immune complex vasculitis can be idiopathic $(45 \%-55 \%)$, or secondary to autoimmune disorders, medications, infections such as HIV or hepatitis C and malignancy. ${ }^{2}$ Workup for immune complex vasculitis with associated LCV should include basic laboratories in addition to inflammatory markers. Additional studies should be focused on identifying an underlying aetiology for the LCV; including workup for SLE, Sjogren's syndrome, antiphospholipid syndrome, HIV, hepatitis $\mathrm{C}$ and malignancy. The diagnosis of LCV is confirmed by histological evidence of perivascular and vascular damage by infiltrating leucocytes as well as fibrinoid necrosis on biopsy. ${ }^{34}$ If LCV is limited to skin involvement, management includes rest, ice, elevation of the legs and addressing the underlying cause. When there is systemic disease, treatment includes corticosteroids with consideration for other immunosuppressive therapies as well. Prognosis is more favourable for those with cutaneous-limited disease rather than those with systemic involvement, with most cases resolving in weeks to months. ${ }^{5}$ Clinicians should be familiar with immune complex vasculitis and its associated dermatological findings. Workup should be focused on identifying the precipitating cause, and treatment is focused around supportive management 
with the addition of immunosuppressive therapies in systemic disease.

Contributors MK, ZK and EMK worked to format and create the manuscript that was prepared for submission and performed a literature review for this project. MK and ZK were involved in the care of the patient being discussed. MK, ZK, EMK and TP worked to assist with editing of the manuscript and worked to perform a literature review for this manuscript. EMK and TP worked to assist in editing of this manuscript as well as with the formatting/submission of this manuscript.

Funding The authors have not declared a specific grant for this research from any funding agency in the public, commercial or not-for-profit sectors.

Competing interests None declared.

Patient consent for publication Obtained.
Provenance and peer review Not commissioned; externally peer reviewed.

\section{REFERENCES}

1 Ratzinger G, Zelger BG, Carlson JA, et al. Vasculitic wheel - an algorithmic approach to cutaneous vasculitides. J Dtsch Dermatol Ges 2015;13:1092-117.

2 Crowson AN, Mihm MC, Magro CM. Cutaneous vasculitis: a review. I Cutan Pathol 2003;30:161-73.

3 Fiorentino DF. Cutaneous vasculitis. J Am Acad Dermatol 2003;48:311-44.

4 Sunderkötter $\mathrm{CH}$, Zelger $\mathrm{B}$, Chen $\mathrm{K}-\mathrm{R}$, et al. Nomenclature of cutaneous vasculitis: dermatologic addendum to the 2012 revised international chapel Hill consensus conference Nomenclature of vasculitides. Arthritis Rheumatol 2018;70:171-84.

5 Einhorn J, Levis JT. Dermatologic diagnosis: leukocytoclastic vasculitis. Perm J 2015;19:77-8.

Copyright 2020 BMJ Publishing Group. All rights reserved. For permission to reuse any of this content visit

https://www.bmj.com/company/products-services/rights-and-licensing/permissions/

BMJ Case Report Fellows may re-use this article for personal use and teaching without any further permission.

Become a Fellow of BMJ Case Reports today and you can:

- Submit as many cases as you like

- Enjoy fast sympathetic peer review and rapid publication of accepted articles

- Access all the published articles

Re-use any of the published material for personal use and teaching without further permission

Customer Service

If you have any further queries about your subscription, please contact our customer services team on +44 (0) 2071111105 or via email at support@bmj.com.

Visit casereports.bmj.com for more articles like this and to become a Fellow 